\title{
DETERMINATION OF FEMALE TABLE TENNIS SPORT PERFORMANCE BY SENZOR MOTORIC REACTION TIME
}

\author{
Hornigova Henrieta ${ }^{1}$ \\ Dolezajova Ladislava² \\ Sedlacek J aromir ${ }^{3 *}$ \\ Sagat Peter ${ }^{4}$ \\ Balint Gheorghe 5 \\ 1,2Comenius University, 84105 Bratislava, Slovakia \\ 3Presov University, 08001 Presov, Slovakia \\ ${ }^{4}$ Prince Sultan University, 11586 Riyadh, Kindom of Saudi Arabia \\ 5"Vasile Alecsandri" University of Bacău, 157 Calea Mărășești, 600115, Romania
}

Key words: table tennis, disjunctive reaction-speed abilities, FITRO agility check

\begin{abstract}
In the sport performance structure of table tennis is sensor motor reaction time one of the most important factors for reaching top-level results, both in males and females groups. In this research we watched 23 female table tennis players from Slovakia; 9 mini cadets (12-13 years), 6 cadets (14-15 years) and 8 juniors (16-18 years). Girls were tested by modified agility test for table tennis players (Vacenovsky \& Vencurik, 2013) with machine FITRO Agility check. Thus we gained their sensor motor reaction times. By Mann-Whitney U-test we studied differences between age categories, upper and lower extremities, dominant (forehand) and un-dominant (backhand) side, right and left-handed players. We used significance level $\mathrm{p}<0.05$. In our research we did not confirm expected results that the older groups have shorter sensor motor reaction time. We also expected shorter reaction time of upper extremities comparing lower extremities; this was confirmed, though there was found statistical significant difference only in juniors group. Groups of mini-cadets and cadets have better (shorter) sensor motor reaction time from backhand side, while group of junior is better from forehand side. We also confirmed that left-handed players have slightly shorter reaction time.
\end{abstract}

\section{Introduction}

Sport game table tennis belongs to the most mass games all over the world. Estimations say that about 300 million people are regularly playing it. Among its advantages can be stated possibility to play it all over the year, at any age, rivals can be both sexes without any special somatic and motor demands.

In the sport performance structure can be traditionally found factors:

\footnotetext{
* E-mail:jaromir.sedlacek47@gmail.com, tel: 00421903177259
} 
a. Genetic (endogenous)

b. Physical development (body height, body weight, percentage of fat tissue, length of extremities)

c. Motor parameters (level of general, special and specific condition and coordinative abilities, special agility, etc.)

d. Psychological qualities (emotional, willing, concentration, anticipation, creativity and activation, regulation of psychological state)

e. Functional performance (aerobic and anaerobic, level of analyser evaluation, blood lactate tolerance)

Outdoors (exogenous)

1. Sport training and competitive parameters

2. Playing (variable and unexpected situations, style and way of rival playing, change of game pace, timing etc.)

3. Player material adaptation (qualities of rackets, coverings and rubbers, balls, tables)

4. Climatic conditions (temperature and humidity in playing room)

Further we can also mention specific signs of table tennis sport performance (Demetrovic, 2003). These specific signs are mostly demands for highest possible level of speed abilities:

1. Reaction speed, that is determined by genetic; development of this ability is possible only by adequate sport training

2. Movement speed means start speed and acceleration from action standing

3. Speed of player movement in playing space, that is coordinative ability of lower extremities

4. Speed of direction change movement of player body

5. Velocity of hit action

6. Frequency of player movement

Present table tennis rules enable choose various types of rackets and coverings, which are officially approved; the only condition is to have distinguished both sides of bat by colours, one must be black and second red. Choose of woods, rubbers and sponges have great influence on hits technique and on the way of tactical playing.

Racket wood can be harder or softer and this influences ball velocity (harder wood means shorter contact time with the bat and greater ball velocity; softer wood enables longer contact time with the ball and this means better feeling of it). Coverings (rubbers) can be with pimples outwards or inwards, with or without sponge. Each rubber has certain level of friction. These stated parameters through their special physical qualities and player movements and hits give to balls certain velocities, trajectories and rotations. New materials enable to give balls higher speed and rotations, or nullify them. Through very low friction of racket covering (rubber) can be upper rotation also transmitted to lower rotation, when ball returns back (Sagat, 2013; Hornikova, 2016). 
Some biomechanical measurements say that ball can reach velocities up to180 km/ h (drives), rotations can reach up to $150{\mathrm{r} . \mathrm{s}^{-}}^{1}$ by upper rotation (offensive hits like topspins, sidespins or drives) or up to 50 r.s- ${ }^{1}$ by lower rotation (defensive hits like chops or blows). Ball flight times between players rackets differs from $100 \mathrm{~m} . \mathrm{s}^{-}{ }^{1}$ to $500-600 \mathrm{~m} . \mathrm{s}^{-}{ }^{1}$. From these stated parameters we can see that in table tennis are very important abilities like reaction time with adequate and fast response.

Reaction time belongs to coordinative abilities that are connected mostly with functions of organism analysers and central nervous system. They are not so genetically determined (except reaction time) and they can be developed practically in each age. During organism growing there exist so called sensitive periods for more progressive coordinative abilities development. They are manifested mostly in age from 7 to 13 years (Belej, 2001; Lednicky, 2002; Simonek et al. 2006).

There can be distinguished simple and complex reaction. In case of simple reaction there is in advance known kind of signal and response; it is more genetically determined. In case of complex reaction we do not know kind of signal, nor response on it. To this kind of reaction belongs reaction with the selection (possibility to choose among more possibilities). Reaction with the selection lasts approximately about $0.3 \mathrm{~s}$ longer like simple reaction. The more alternatives for selection you have the longer time you need (Zemkova \& Hamar, 2015). Here plays very important role anticipation like ability to predict beginning, course, lasting and possible result of motor activity (Simonek et al. 2006).

Reaction time can be also developed by various kind of stimulus. It seems that the shortest reaction time is reached with contact stimulus ( $\mathrm{Ng} \&$ Chan, 2012). Noise stimulus is faster like visual stimulus (Shelton - Kumar, 2010).

Another factor is sex. Most studies confirm that males have better (shorter) reaction times, mostly in case of simple reaction time (Dane \& Erzurumluoglu, 2003; Dykiert et al. 2012; Karia et al. 2012).

More authors studied reaction time with its dependence of age. Zemkova and Hamar (2015) proved that disjunctive reaction time gets shorter with growing till early adulthood. There are three phases; the greatest fall was found at age $7-10$ years $(27.1 \%)$ and $10-14$ years $(26.5 \%)$. Lower fall was found at age of puberty from $14-18$ years (16.5\%). According Der and Deary, 2006 the reaction time with higher age gets shorter and is more variable, too. At age about 50 years simple reaction time gets slightly worse, but selection reaction time gets worse during all period of adulthood.

Another factor for different reaction time is laterality. Left handed players have better dispositions for shorter reaction time due to physiological reasons, when cerebral hemispheres specializations are different and this enables shorter reaction times by left handed players. This also confirmed more researchers (Chittibabu, 2014; Cherbuin \& Brinkman, 2006; Dane \& Erzurumluoglu, 2003; Gajdoschik, 2014). 
There were also found differences in reaction times between upper and lower extremities. The explanation why noise and visual stimulation is shorter with upper extremities is in shorter length from the centre (cerebrum) and thus also with shorter motor response. It was confirmed, too by more authors (Misra et al. 1985; Chan \& Chan, 2010; Mali et al. 2013).

Some authors found that warming can slightly shorter reaction time (Stulrajter, 1987; Chatzopoulos et al. 2014; Vacenovsky et al. 2015). On the other side the movement load has negative influence on all kind of reaction times (Zemkova \& Hamar, 2001; Kondric et al., 2010; Sabzi, 2012). Some authors found that higher level of sport performance correspond also with shorter reaction times (Stulrajter, 1987; Streskova, 2002; Thonessen et al. 2013).

Reaction times both simple, or complex (disjunctive) were found shorter by many researchers in all rackets sports (table tennis, badminton, tennis, squash). Zemkova \& Hamar (2015) showed in agility tests, where they measured sensor motor time that rackets players were significantly better (shorter) comparing other sports. Similar results reached Cam et al. (2014) and Ak and Kocak (2010) on groups of young sportsmen. Even special training (with rackets) can improve reaction times Vacenovsky and Vencurik (2013).

Generally we can say that in table tennis the player must in a very short time estimate ball velocity, ball trajectory (direction) and magnitude of ball rotation and react in adequate way. For successful playing there is the need to possess the highest possible level of sensor motor (disjunctive) reaction time qualities; this is the most important factor to reach top-level sport performance in this game.

Objectives. Aim of the research was to highlight different level of disjunctive reaction-speed abilities of $12-18$ year old table tennis girls.

\section{Material and Methods}

Hypothesis

1. Older girls will have shorter disjunctive reaction time

2. Reaction time of upper extremities will be shorter comparing lower extremities

3. Reaction time will be shorter from dominant (forehand) side comparing un-dominant (backhand) side

4. Left-handed players will have shorter reaction time like right-handed

In our research were involved 23 table tennis girl players from Slovakia from 12 to 18 years of age. Fundamental characteristics can be seen in tab 1 .

Table 1 Fundamental characteristic of our girl groups

\begin{tabular}{|c|c|c|c|}
\hline Medians & Mini cadet $(\mathrm{n}=9)$ & Cadet $(\mathrm{n}=6)$ & Junior $(\mathrm{n}=8)$ \\
\hline Decimal age $($ years) & 13.2 & 14.6 & 16.6 \\
\hline Body height $(\mathrm{cm})$ & 164 & 165 & 169.5 \\
\hline Body weight $(\mathrm{kg})$ & 43 & 55 & 63.5 \\
\hline $\begin{array}{c}\text { Sport specialization } \\
\text { (years) }\end{array}$ & 6 & 7 & 8.5 \\
\hline
\end{tabular}


We measured these variables: body height and body weight, date of birth (decimal age) and length of specialization (sport specialization). Disjunctive reaction time was measured with apparatus FiTRO Agility check (adjusted test for table tennis reaction time, Vacenovsky \& Vencurik, 2013). Our girls started from the distance $40 \mathrm{~cm}$ (originally it is $75 \mathrm{~cm}$ ) due to their age with lower body height like adults from action standing. The task was to touch as fast as possible one of the four contact plates by their dominant upper or lower extremity. That is why right handed players reacted by right and left handed by left upper or lower extremity. Two plates were in table corners and two were on the floor beneath the table. The touch with the plate was concordant with visual stimulus projected in one of the corners of pc screen. Like a stimulus we used yellow circle on blue background. Test consists by 2 times 16 random attempts generated by pc (4 into each direction) and with fixed time generation $2000 \mathrm{~ms}$; result of the test is an average of 4 scores in better attempt from 2 attempts (Fig 1).

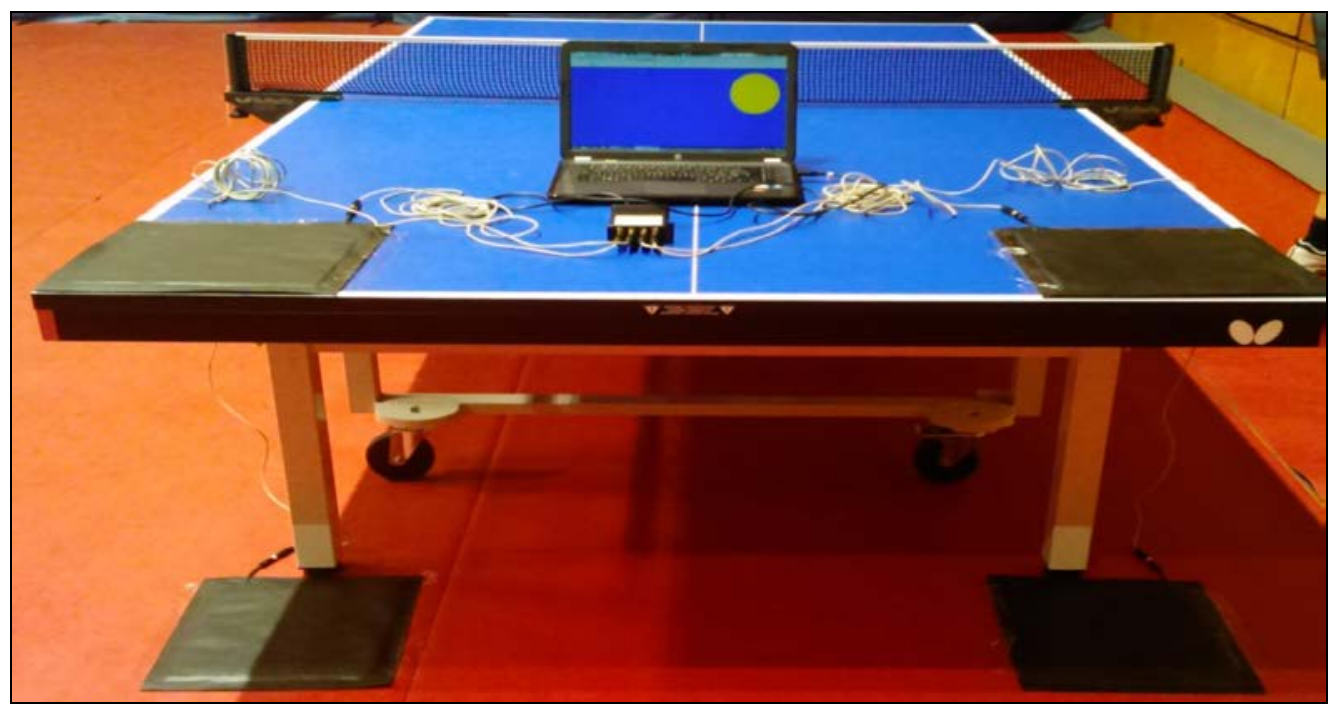

Figure 1. Realization of measurements with Fitro Agility check

By measurements we gained fundamental statistic characteristics (median, maximum and minimum values and variation range). For reaching statistically significant differences between various groups there was used Man-Whitney Utest and we were working with significance level $\mathrm{p}>0.05$.

In pedagogical interpretation we used fundamental logical methods like analyse, deduction, comparison and generalization.

\section{Results and discussions}

1. Relationship between reaction time and age of our girl groups

The first hypothesis supposes that the older the group is, the shorter reaction time will possess. In table 2 we can see fundamental statistical data with regard of age. 
Table 2 Statistical data of disjunctive reaction time of our groups with regard of age

\begin{tabular}{|c|c|c|c|}
\hline Parameters & $\begin{array}{c}\text { Mini cadets }(\mathrm{n}=9) \\
{[\mathrm{ms}]}\end{array}$ & $\begin{array}{c}\text { Cadets }(\mathrm{n}=6) \\
{[\mathrm{ms}]}\end{array}$ & $\begin{array}{c}\text { Juniors }(\mathrm{n}=8) \\
{[\mathrm{ms}]}\end{array}$ \\
\hline Median & 811.4 & 854.1 & 843.1 \\
\hline Xmax & 980.6 & 905.8 & 905.1 \\
\hline Xmin & 631.8 & 771.2 & 714.4 \\
\hline $\mathrm{Vr}$ & 348.8 & 134.6 & 190.7 \\
\hline
\end{tabular}

It can be seen that the shortest reaction time possesses the younger group of mini cadets. The second shortest time possesses the group of juniors and the longest reaction time has the group of cadets. Differences between mini cadets and cadets were $5 \%$ and between mini cadets and juniors $4 \%$. In spite of it the differences did not reach statistically significant level (Fig 2).

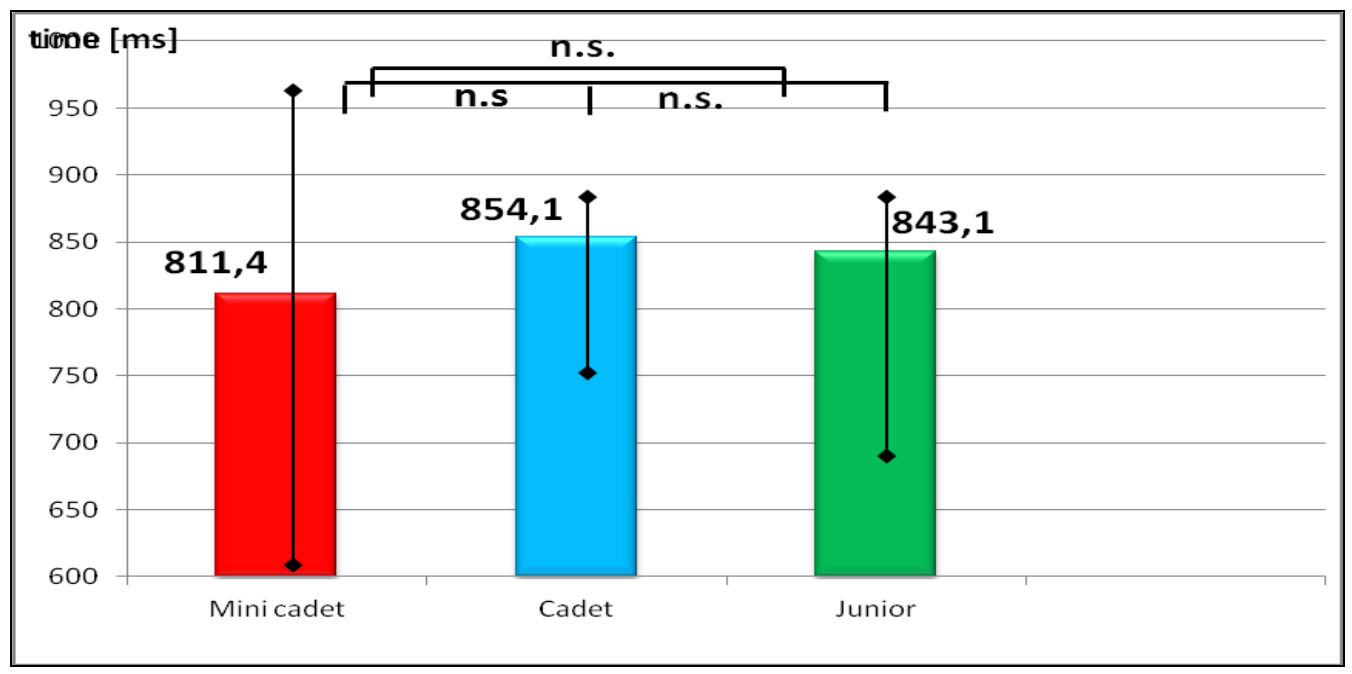

Figure 2. Statistical significance between our groups

It seems that the homogeneity of mini cadets was too low, for the variation range was extremely great. This could influence the result. We must say that we did not confirm this first hypothesis.

2. Relationships of reaction times between upper and lower extremities The second hypothesis supposes that upper extremities possess shorter reaction times. In table 3 can be seen fundamental statistical data with regard of upper and lower extremities. 
Table 3 Statistical data of disjunctive reaction time of our groups with regard of upper and lower extremities

\begin{tabular}{|c|c|c|c|c|c|c|}
\hline \multirow{2}{*}{ Parameters } & \multicolumn{2}{|c|}{ Mini cadets (n=9) } & \multicolumn{2}{c|}{ Cadets (n=6) } & \multicolumn{2}{c|}{ Juniors (n=8) } \\
\cline { 2 - 7 } & $\begin{array}{c}\mathrm{UE} \\
{[\mathrm{ms}]}\end{array}$ & $\begin{array}{c}\mathrm{LE} \\
{[\mathrm{ms}]}\end{array}$ & $\begin{array}{c}\mathrm{UE} \\
{[\mathrm{ms}]}\end{array}$ & $\begin{array}{c}\mathrm{LE} \\
{[\mathrm{ms}]}\end{array}$ & $\begin{array}{c}\text { UE } \\
{[\mathrm{ms}]}\end{array}$ & $\begin{array}{c}\text { LE } \\
{[\mathrm{ms}]}\end{array}$ \\
\cline { 2 - 7 } Median & 741.4 & 856.3 & 811.3 & 857.9 & 791.4 & 908.7 \\
\hline Xmax & 1055.3 & 1036.8 & 988 & 995.3 & 921.5 & 1036 \\
\hline Xmin & 528.2 & 676 & 660.8 & 767.5 & 558.5 & 809.3 \\
\hline $\mathrm{Vr}$ & 527.1 & 360.8 & 327.2 & 227.8 & 363 & 226.7 \\
\hline
\end{tabular}

Legend: UE - upper extremity; LE - lower extremity

In each category reached shorter sensor motoric reaction time upper extremity; it can be also seen on figure 3. At mini cadets lower extremities were backward about $13 \%$, at cadets it was $6 \%$ and at juniors it was $15 \%$. By individual monitoring of each girl we can mention that some of them had shorter reaction time with lower extremities, mainly at mini cadets group. Variation range in each group was enough large; statistic significant difference can be seen only in group of juniors (Fig 3).

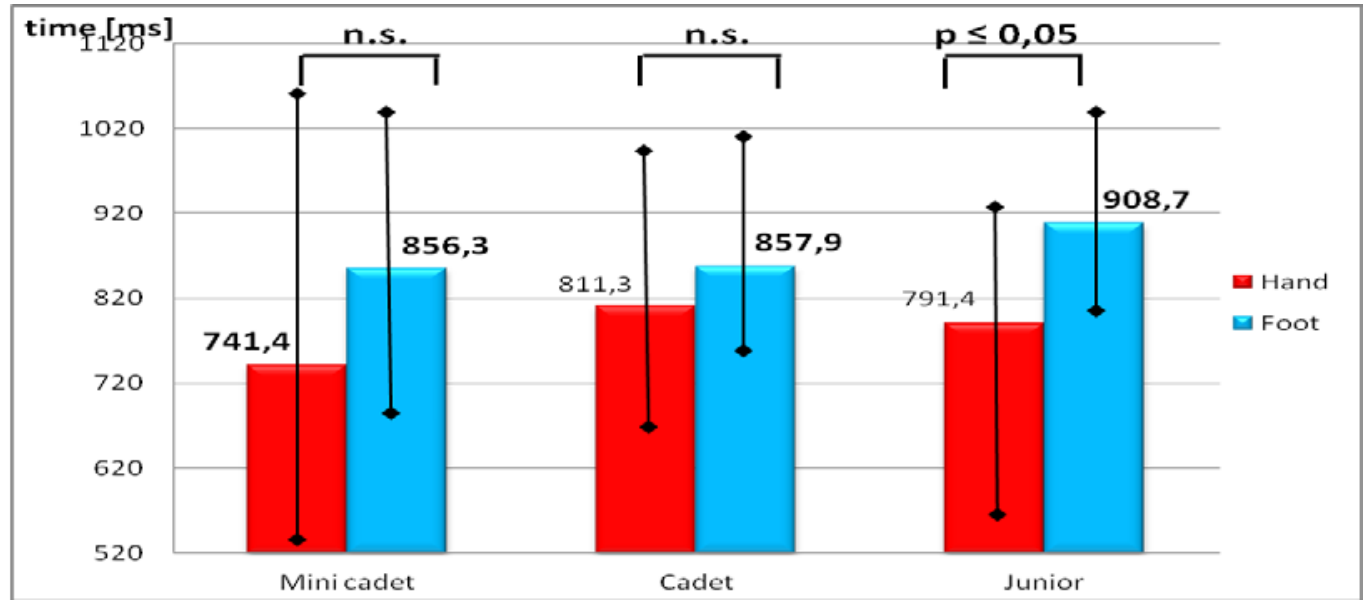

Figure 3. Statistical significance between upper and lower extremities in our groups

Our assumption that upper extremities possess shorter reaction time comparing lower extremities was confirmed, though statistical significance can be seen only in group of juniors.

3. Reaction time comparison between dominant (forehand) and undominant (backhand) side

Fundamental statistical characteristics can be seen in Tab 4 . 
Table 4 Statistical characteristics of reaction times between forehand (dominant) and backhand (un-dominant) side

\begin{tabular}{|c|c|c|c|c|c|c|}
\hline \multirow{2}{*}{ Parametrs } & \multicolumn{2}{|c|}{ Mini cadets (n=9) } & \multicolumn{2}{c|}{ Cadets (n=6) } & \multicolumn{2}{c|}{ Juniors (n=8) } \\
\cline { 2 - 7 } & $\begin{array}{c}\text { Forehand } \\
{[\mathrm{ms}]}\end{array}$ & $\begin{array}{c}\text { Backhand } \\
{[\mathrm{ms}]}\end{array}$ & $\begin{array}{c}\text { Forehand } \\
{[\mathrm{ms}]}\end{array}$ & $\begin{array}{c}\text { Backhand } \\
{[\mathrm{ms}]}\end{array}$ & $\begin{array}{c}\text { Forehand } \\
{[\mathrm{ms}]}\end{array}$ & $\begin{array}{c}\text { Backhand } \\
{[\mathrm{ms}]}\end{array}$ \\
\hline Median & 749 & 733.8 & 846.7 & 801.5 & 698.7 & 820.9 \\
\hline Xmax & 1055.3 & 901.3 & 960.3 & 943.8 & 905.8 & 921.5 \\
\hline Xmin & 528.3 & 610.8 & 772.3 & 678.3 & 562.3 & 558.5 \\
\hline $\mathrm{Vr}$ & 527 & 290.5 & 188 & 265.5 & 343.5 & 363 \\
\hline
\end{tabular}

According our results we can see that at groups of mini cadets and cadets have slightly shorter reaction times on backhand (un-dominant) side. Only group of juniors fulfils our assumptions that from dominant (forehand) side is reached shorter reaction time (difference is clear - about 17.5\%)

Forehand is a hit by which is playing arm in more natural position like by backhand hits. It is considered like easier and most natural hit. Backhand is considered like more difficult hit, for it starts from un-dominant (backhand) side, racket is up to certain level pulled by arm and the force of the hit does not reach so greatness like by forehand. Sedlacek, 2005 by watching forehand and backhand hits of table tennis players stated conclusion that the speed parameters at node phases are so different in favour of forehand hits that there is logical effort of majority players to prefer forehand hits. That is why we were thinking that even our girl groups will have shorter reaction times from forehand (dominant) side. Our assumptions were fulfilled only at group of juniors. Thus we did not confirm our hypothesis. We can suppose that in this case the length of specialization with practical competitive experience could lead our juniors to prefer forehand hits like more effective hits for reaching winning points.

4. Reaction time comparison between right and left handed girl players

In our groups we found majority right-handed girls; the rate was 19 to 4 . In table 5 are fundamental statistical data for this case of comparing reaction time according laterality.

Table 5 Statistical characteristics of reaction times between right and left-handed girls

\begin{tabular}{|c|c|c|}
\hline Parameters & $\begin{array}{c}\text { Right handed }(\mathrm{n}=19) \\
{[\mathrm{ms}]}\end{array}$ & $\begin{array}{c}\text { Left handed }(\mathrm{n}=4) \\
{[\mathrm{ms}]}\end{array}$ \\
\hline Median & 818.9 & 812.7 \\
\hline Xmax & 980.6 & 909.3 \\
\hline Xmin & 631.8 & 714.4 \\
\hline $\mathrm{Vr}$ & 348.8 & 194.9 \\
\hline
\end{tabular}


Comparison of reaction times between right and left handed girls showed slight difference (1\%) in favour of shorter sensor motor reaction times of lefthanded players. This confirms our assumption, but only four left handed girls does not afford us to generalize this peace of knowledge.

There are some research works that deal with influence of laterality on reaction times. They mostly refer on higher effectiveness of left-handed people who are able to use better their dominant hemisphere (Cherbuin \& Brinkman, 2006). This is confirmed also in work of Gajdoschik, 2014, where left-handed players had average values of disjunctive reaction time clearly better like right handed ones.

\section{Conclusions}

1. We did not confirm statistically significant difference in reaction time from the point of decimal as well as sport age. Our results are rather different like some researches in this field.

2. We confirm shorter reaction time of upper extremities comparing lower extremities though we expected more clear statistics differences.

3. We did not confirm shorter disjunctive reaction time from dominant (forehand) side; only in junior category it was like we had our expectations.

4. From the point of laterality we measured better results like we expected it from former researches. But quantity of left handed players in our research was only 4 girls; though generalization could be doubtful.

\section{References}

1. AK, E., KOCAK, S. (2010). Coincidence-anticipation timing and reaction time in youth tennis and table tennis players, In: Perceptual and Motor Skills (online), $110 \quad$ (3), 879-887 [cit. 2016-04-20]. http://www.amsciepub.com/doi/abs/10.2466/pms.110.3.879-887;

2. BELEJ, M. (2001). Motorické učenie (Motor learning). Prešov: Fakulta humanitných a prírodných vied PU v Prešove;

3. DANE, S., ERZURUMLUOGLU, A. (2003). Sex and handedness differences in eye-hand visual reaction time in handball players, In: International Journal of Neuroscience (online), 113(7), 923-929 [cit. 2016-4-03]. http://www.ncbi.nlm.nih.gov/pubmed/12881185;

4. DEMETROVIĆ, E. (2003). Stolný tennis, Bratislava: Slovenský stolnotenisový zväz;

5. DER, G., DEARY, I. J. (2006). Age and sex differences in reaction time in adulthood: Results from United Kingdom Health and Lifestyle Survey. In: Psychology and Aging (online), 21(1), 62-73 [cit. 2016-3-30] http://www.ncbi.nlm.nih.gov/pubmed/16594792; 
6. DYKIERT, D., DER, G., DEARY, I. J. (2012). Sex differences in reaction time mean and intraindividual variability across the life spine. In: Developmental Psychology (online), 48(5), 1262-76 [cit. 2016-3-30]. http://www.ncbi.nlm.nih.gov/pubmed/22390656;

7. GAJDOSCHÍK, A. (2014). Úroveň vybraných koordinačných schopností 14- až 18-ročných reprezentantov v stolnom tenise (Level of selected coordinative abilities 14-18 years old Slovak representants in table tenis). Bratislava. Bakalárska práca. Univerzita Komenského v Bratislave, Fakulta telesnej výchovy a športu, Katedra atletiky;

8. HORNIKOVA, H. (2016). Úroven vybratych koordinacnich schopnosti stolnych tenistiek podla veku. (Level of selected coordinative table tennis abilities from the point of age), Bratislava: Comenius University, Bc. Thesis. p.49;

9. CHAN, K. W. L., CHAN, A. H. S. (2010). Stimuls-uresponse compatibility effect for hand and foot controls with visual signals on eccentric and central positions in horizontal orientation, Ergonomic Trends from the East (online), London: Talor \& Francis Group, s. 95-99 [cit. 2016-04-18];

10. CHATZOPOULOS, D., GALAZOULAS, CH., PATIKAS, D., KOTZAMANIDIS, CH. (2014). Acute effects of static and dynamic stretching on balance, agility, reaction time and movement time. In: Journal of Sport Science and Medicine (online), 13(2), 403-409 [cit. 201604-13]. http://www.jssm.org/researchjssm-13-403.xml.xml;

11. CHERBUIN, N., BRINKMAN, C. (2006). Hemispheric interactions are different in left-handed individuals, Neuropsychology [online], 20 (6), 700 - 707 [cit. 2016-3-30]. http://www.ncbi.nlm.nih.gov/pubmed/17100514;

12. CHITTIBABU, B. (2014). Analysis of Handedness on the Visual Reaction Time in Male Handball Players, International Journal of Recent Research and Applied Studies (online), 3(10), 42-44 [cit. 2016-01-02] http://www.ijrras.com/aug2014volume1issue3;

13. KARIA, R. M., GHUNTLA, T. P., MEHTA, H. B., GOKHALE, P. A., SHAH, CH. J. (2012). Effect of Gender difference on Visual Reaction Time: A Study On Medical Students of Bhavnagar Region, IOSR Journal of Pharmacy (online), 2(3), 452-454 [cit. 2016-04-03], ISSN 2250-3013. http://www.iosrphr.org/papers;

14. KONDRIČ, M., MANDIČ, G. F., KONDRIČ, L., GABAGLIO, A. (2010). Physiological demands and testing in table tennis. In: Interna tional Journal of Table Tennis Sciences (online), No 6, 165-170 [cit. 201604-24];

15. LEDNICKÝ, A. (2002). Koordinačné schopnosti v telesnej výchove a tréningovom procese mládeže, ich charakteristika a význam. In: DOLEŽAJOVÁ L. a A. LEDNICKÝ. Rozvoj koordinačných schopností (Development of coordinative abilities). Bratislava: ICM Agency 
16. MALI, B. Y., BHATKAR, R. S., PRADHAN, M. P. (2013). Comparison of Visual and Auditory Reaction Time of Hand and Foot in Young Adults Before and After Physical Training, Indian Medical Gazette (online), 257260 [cit. 2016-01-02]. http://medind.nic.in;

17. MISRA, N., MAHAJAN, K. K., MAINI, B. K. (1985). Comparative study of visual and auditory reaction time of hands and feet in males and females. In: Indian journal of physiology and pharmacology (online), 29 (4): s. 213-218 [cit. 2016-2-07]. http://www.ijpp.com/IJPP;

18. NG, A. W. Y., CHAN, A. H. S. (2012). Finger response time to visual, auditory and tactile modality stimuli (online), Hong-Kong: IMECS [cit. 2016-04-09]. http://www.iaeng.org/publication/IMECS2012/IMECS2;

19. SABZI, A. H. (2012). The effect of different fatigue protocols on choice reaction time, Middle-East Journal of Scientific Research (online), 12(8), 1092-1096 [cit. 2016-04-13].

http://www.idosi.org/mejsr/mejsr12(8)12/9.pdf;

20. SEDLÁČEK, J. (2005). Porovnanie vybraných kinematických parametrov európskych a čínskych stolných tenistov (Comparison of selected kinematic parameters table tennis players from China and Europe). In: SEDLÁČEK, J. Kinematická štruktúra pretekovej a tréningovej pohybovej činnosti a jej zmeny $v$ tréningovom procese športovcov rôznych špecializácií s prihliadnutím na somatické charakteristiky. Bratislava: ICM Agency, s. 104-108;

21. SHELTON, J., KUMAR, G. P. (2010). Comparison between auditory and visual simple reaction time. In: Neuroscience and Medicine (online), 1(1), 30-32 [cit. 2016-04-09]. http://file.scirp.org/pdf/;

22. STREŠKOVÁ, E. (2002). Prínos zist'ovania úrovne disjunktívnych reakčno - rýchlostných schopností v stolnom tenise (Contribution of testing level of disjunctive reaction speed abilities in table tennis), Acta Facultatis Educationis Physicae Universitatis Comenianae, XLIII, s. 147151 ;

23. ŠAGÁT, P. (2013). Vplyv vybraných osobnostných vlastností na športový výkon stolných tenistov a tenistiek (Influence of selected personal qualities on sport performance male and female table tennis players), Bratislava. Dizertačná práca. Univerzita Komenského v Bratislave, Fakulta telesnej výchovy a športu, Katedra humanistiky;

24. ŠIMONEK, J., ŠIMONEK, J. jr. (2006). Reakčné schopnosti (Reaction abilities). In: ŠIMONEK, J., J. ŠIMONEK ml., M. MIKUŠ, V. LAFKO, J. MIHALČIN, T. SLANČOVÁ a J. RUBICKÁ. Koordinačná príprava $v$ športových hrách, Prešov: Expres Print, s. 11-22;

25. ŠTULRAJTER, V. (1987). Reakčný čas ako ukazovatel' adaptácie na zat'aženie $\mathrm{v}$ športe (Reaction time like adaptation parameter of load in sport). In: Acta Facultatis Educationis Physicae Universitatis Comenianae, $X X V$, s. 72-120; 
26. THONNESSEN, E., HAUGEN, T., SHALFAWI, S. A. I. (2013). Reaction time aspects of elite sprinters in athletic world championships, The Journal of Strength and Conditioning Research [online]. 27(4), 885-892 [cit. 2016-04-05]. https://www.researchgate.net/publication;

27. VACENOVSKÝ, P., VENCÚRIK, T. (2013). Improvement of reaction time through the one semester course of table tennis for non-athlete students, Sport and Quality of Life 2013 (online), Brno: Masarykova univerzita, s. 200-207 [cit. 2015-3-17]. http://conference2013.fsps.muni.cz/ ;

28. VACENOVSKÝ, P., VENCÚRIK, T., SEBERA, M. (2015). Reaktivní agilita před a po sportovně-specifickém rozcvičení u hráčů stolního tenisu (Reactive agility before and after sport specific warming at table tennis players). In: Studia Sportiva [online]. Brno: Masarykova Univerzita, 2015, č. 1, 38-44 [cit. 2016-4-30]. https://www.muni.cz/research/publications/;

29. ZEMKOVÁ, E., HAMAR, D. (2015). Toward an Understanding of Agility Performance - $2^{\text {nd }}$ edition. Boskovice: František Šalé - Albert;

30. ZEMKOVÁ, E., HAMAR, D. (2001). Posudzovanie disjunktívnych reakčno -rýchlostných schopností (Evaluation of disjunctive reaction abilities). Bratislava: Cart print, s.r.o. 